Araştırma Makalesi / Research Article

\title{
SAVAŞA DÜŞEN MAHKÛMA SARILIR MI? 1. DÜNYA SAVAŞI BAŞLARINDA OSMANLI DEVLETI'NİN MAHKÛMLARDAN FAYDALANMA DÜŞÜNCESİ
}

\author{
Mustafa Firat GÜL* \\ THE THOUGHT OF OTTOMAN EMPIRE TO BENEFIT \\ FROM CONVICT IN THE FIRST WORLD WAR
}

\begin{abstract}
Öz
Birinci Dünya Savaşı dünya tarihi ve Türk tarihi açısından en önemli savaşlardan biridir. Bu savaşın yıkıcı etkisi ve diğer tesirleri oldukça geniş olmuştur. Savaşın kaybedenler safında yer alan Osmanlı Devleti'nin 1914 başlarında da iyi durumda olduğu söylenemez. Hem içeride hem de dişarıda pek çok sorunla meşgul olmuştur. Trablusgarp Savaşı'yla başlayıp Balkan Savaşlarıyla devam eden süreçte Birinci Dünya Savaşı Osmanlı Devleti'nin mecalini iyice tüketmiştir. İttifak yaptığı devletlerden Almanya'nın her konuda desteğini bekleyen Osmanlı Devleti kendi kaynaklarını da hem tasarruflu kullanmak hem de duruma göre son raddesine kadar değerlendirmek zorunda kalmıştır. Asker sayısını artırmak için çeşitli suçlardan hapishanelerde tutuklu bulunan mahkûmların bazılarından asker olarak faydalanmayı düşünmüştür. Ancak başta mantıklı gibi gelen bu fikrin kısa süre sonra işe yaramadığ anlaşılmıştır. $\mathrm{Bu}$ çalışma, Osmanlı Arşivlerinde yer alan belgelerin ışı̆̆ında özellikle Kafkas Cephesi'nde Osmanlı hapishanelerindeki mahkûmlardan cephede asker olarak faydalanma fikrine odaklanmaktadır.
\end{abstract}

Anahtar Kelimeler: 1. Dünya Savaşı, Türk Ordusu, Kafkas Cephesi, Mahkûmlar, Gönüllüler.

\begin{abstract}
The First World War is one of the most important wars in world history and Turkish history. The destructive effect and other effects of this war, which lasted approximately four years, were quite wide. It cannot be said that the Ottoman State, which was among the losers in the First World War, was in good condition in the beginning of 1914 as well. It has been busy with many problems both inside and outside. During the process that started with the Tripoli War and continued with the Balkan Wars, the First World War consumed the medal of the Ottoman Empire. The Ottoman State, which is waiting for the support of Germany in all matters from the states that it makes alliance, has to use its own resources both economically and according to the situation until the last point.
\end{abstract}

* Dr. Aksaray Belediyesi Azm-i Milli Bilim ve Sanayi Müzesi, e-posta: mustafafiratgul@gmail.com, https://orcid.org/0000-0001-9023-4131.

Makale Gönderim Tarihi: 29.06.2020 https://doi.org/10.11616/basbed.v20i56819.760346 Makale Kabul Tarihi $\quad: 17.09 .2020$ 
To increase the number of soldiers, he considered being a soldier among some of the prisoners detained in prisons for various crimes. It seemed that this idea, which seemed logical at first, did not work soon. In the light of the documents in the Ottoman Archives, this study focuses on the idea of benefiting from prisoners in Ottoman prisons as soldiers in the front, especially in the Caucasian Front..

Keywords: World War I, Turkish Army, Caucasian Front.

\section{Giriş}

Osmanlı Devleti, özellikle 19. yüzyılın sonlarında zorlu bir dönem yaşamıştır. Savaşlar, yokluklar, yoksulluklar halkı perişan etmiştir. 20. Yüzyılın başlarında önce Trablusgarp akabinde Balkan Savaşı'nın acısını yaşayan asker ve halk moralini yitirmişti. Ama daha bu savaşın muhasebesi bitmeden Birinci Dünya Savaşı patlak verdi. Gerçi bu savaşın da oldu bitti ile başlamadığı, pek çok hadisenin varlığı ve ilerleyişi savaşın beklenen bir durum olduğunu göstermektedir. Osmanlı Devleti özellikle 1914 Temmuz'undan sonra teyakkuz durumundadır. Çevresinde, Avrupa'da, dünyada olup bitenlere dikkat kesilen Osmanlı Devleti çok hızlı değişebilen siyasetin uzağında kalamayacağını bildiğinden duruma göre pozisyon almaya çalışmıştır. Her türlü ihtimale karşı da askeri yönden hazırlıklarını devam ettirmiştir. Dönemin şartları gereğince bu hazırlıklar, tedbirler, hamleler gizlice yürütülmeye çalışılmıştır. Maddi imkanlarının kısıtlı olması sebebiyle de oldukça tasarruflu davranıldığı söylenebilir. Mümkün mertebe temkinli davranmak isteyen Osmanlı Devleti (İttihat ve Terakki) tereddütsüz bir şekilde Almanlarla işbirliği aramak yerine ülkenin menfaatine uygun hatta en uygun ittifak arayışına girmiştir.

19. yüzyılın ilk çeyreğinden itibaren Avrupalıların Osmanlı'yla alakalı hiç de hoş olmayan niyet, plan ve girişimleri olduğu bir hakikattir. Şark Meselesi diye bilinen bu planın aşamalarından birisi Birinci Dünya Savaşı'dır denilebilir. Birinci Dünya Savaşı'ndan önce Avrupa'nın büyük devletlerinin oluşturdukları ittifaklar genişlemiş ve iki blok çıkmıştır. Almanya, Avusturya-Macaristan ve İtalya Üçlü İttifakı; İngiltere, Fransa ve Rusya Üçlü İtilafi oluşturmuşlardır. İtalya daha sonra İtilaf Devletleri safinda yer aldı. Bulgaristan ve Osmanlı Devleti de İttifak Devletleri ile birlik olmayı tercih edince güç dengesi kurulmuş oldu (Turan, 2015: 84). Derinlerdeki ve gerçek sebep Avrupalı büyük devletlerin daha fazla sömürü hırsıdır. Ama görüntüye göre ya da zahirde bir suikast her şeyi alt üst etti ve savaş patlak verdi! 28 Haziran 1914 tarihi pazar günü saat 10.30 'da Gavrilo Princip büyük Sırbistan hülyalarını gerçekleştirmek için Franz Ferdinand ve eşi Sophie'yi öldürünce Birinci Dünya Savaşı'nın fitili yakılmış oldu (Karaca, 2015: 92; Hacısalihoğlu, 2009: 123). Bu 
olay, Avusturya ile Sirbistan arasında bir savaşın çıkmasına ve hemen ardından I. Dünya Savaşı'nın başlamasına yol açtı (Aruçi, 2009: 130; Karal, tarihsiz: 367-369). Pekâlâ, Osmanlı Birinci Dünya Savaşı'na nasıl girdi? Bu da ayrı ve önemli bir sorudur. Osmanlı Devleti'nin Birinci Dünya Savaşı'na girmesi ve Almanlarla yapılan ittifakın savaşın neticelerine olan etkileri uzun zamandır tartışılmaktadır. Keleşyılmaz'ın ifadesiyle "Osmanlı Devleti'nin savaşa girişi belki de savaşın kendisinden daha fazla tartışılmıştır" (1999a: 139).

2 Ağustos 1914'te, İstanbul'da Osmanlı Devleti ile Almanya arasında gizli bir ittifak antlaşması imzalanmıştır. Osmanlı üst düzey yöneticilerinden yalnızca Sultan Mehmet Reşat, Sadrazam Said Halim Paşa, Meclis-i Mebusan Reisi Halil Menteşe, Dâhiliye Nazırı Talat Paşa ve Harbiye Nazırı Enver Paşa'nın bilgisi dâhilinde yürütülen bu ittifak anlaşmasından diğer hükümet yetkilileri ve Meclis-i Mebusan haberdar edilmemiştir (Okur-Göktaş, 2014: 85; (Akşin, 1997: 110).

10 Ağustos 1914'te Akdeniz'de İngiliz donanmasının takibinden kaçan Goeben ve Breslau adlı Alman kruvazörleri Çanakkale Boğazı'na girerek Osmanlı Devleti'ne sığındılar. Devletin tarafsızlığı Alman gemilerinin Türk sularını terk etmesini gerektiriyordu. Bu meseleye hemen şöyle bir çözüm bulundu: Kruvazörler Türk hükümetince satın alındı (Kuran, 1992: 197).

11 Ağustos’ta Almanya'dan 80.000 marka satın alındığ ilan edilen gemilere Osmanlı bayrağı çekilmiş ve personeli de Osmanlı Devleti hizmetine alınmıştır (Ortak, 2015:289). İttihat ve Terakki'nin önemli isimlerinden olan Hafız Hakkı'nın yazdıkları oldukça önemlidir. Bardakçı'nın yayınladığı günlükteki ifadeler şöyledir:

Maatteessüf, sabah donanmamızın düşman donanmasıyla harbe tutuştuğu haberi geldi ve hemen dönmeye mecbur olduk. Alman erkân-ı harbiyesi ile temas eden [...] mezkûr erkan-ı harbiyenin bizden şunlar istediğini anladı: Hemen Karadeniz'e hareket, Misır istikametinde mümkün mertebe çabuk ilerlemek, Cihad-l mukaddes ilan etmek. Ben bunların üçünü de saçma addediyorum. Fakat ne yapalım, madem ki müttefik! Dik Alman kafası, laf anlatmak da kabil değil. Bir kere de harp başlamış! Artık olacak! Harp nasıl başladı: Donanma kumandanına şöyle bir emir hazırlanmış idi: "Rus donanmasını mahvederek Karadeniz hakimiyetini kazanınız. Bu emir benim kasada duruyordu. Ancak icabında ve zamanında verilecekti. Bizim hareketimizden evvel nazır emri istedi. "Suşon'a vereceğim. Kapalı bir zarf içinde. Lazım olduğu zaman emri a! diyeceğim" dedi. Ben şüphelendim. Rica ettim, dinlemedi. Halbuki iş büsbütün başka türlü olmuş ve Suşon kendisi Alman kafasıyla atış, 
yapmış, etmiş. Bizi vakitsiz bir harbe sürüklemiş. Bundan sonra artık vaziyeti selamete çıkarmak için canla-başla çalışmak lazım (2013: 453454).

Resmi olarak savaşa girilmesinden sonra Meclis-i Mebusan'da konu gündeme gelmiştir. İtirazlar olmasına rağmen Meclis savaş fikrine destek çıkmıştır. Meclis Birinci Yasama Yılının ilk toplantısında Başkumandanlık Vekâleti'ne bir tebrik telgrafı gönderilmesine karar vermiştir. "Kahraman Osmanlı Askerleri!" ifadesiyle başlayan telgrafta "milletin ihtiyarından gencine, şehitlerinden dirilerine varincaya kadar" topyekûn savaşa hazır olduğu belirtilmekteydi. Savaş asırlardan beri beklenen intikam günüydü (Yazıc1, 2018: 337).

Bilindiği gibi Osmanlı Devleti ordusunu ıslah etmek istiyordu. Özellikle Balkan Savaşları'ndan yenik ayrılması bu sürecin çok önemli olduğunu daha da hızlanmasının gerekliliğini göstermiştir. Ama ordunun 1slahı için hangi devlet ile görüşülmeliydi? Bu mühim mesele hakkındaki şümullü değerlendirme sonrasında Rusya'ya güvenilemeyeceğine karar verildi ve ordunun 1slahı için Almanlarla anlaşma tercih edildi. Elbette bu o kadar kolay olmadı. Başta Rusya engel olmak istedi. Rusya’nın menfi tavrına rağmen Alman Askeri Heyeti, General Liman von Sanders Paşa başkanlığında İstanbul'a gelerek göreve başlamıştı (Karaca, 2011: 207).

1913 'te General Otto Liman von Sanders'in başkanlığındaki yeni Alman askerî yardım heyetiyle, sadece Osmanlı ordusunda değil, imparatorluğun her örgüt ve köşesinde Alman nüfuzu artmaya başladı. Osmanlı Genelkurmay Karargâhı Kıdemli Başkanlı̆̆ı görevine getirilen Prusya Albayı Bronsart von Schellendorf, 20 Ağustos 1914'ten itibaren olası savaş durumunda açılacak cephelerle ilgili planları hazırlamaya başladı. Savaş başladığında artık denetim mutlak olarak von Schellendorf'un, başka bir deyişle Alman Genelkurmayı'nın elindeydi" yorumu ise gayet isabetlidir (K1lıç, 2014: 99-100).

Almanlar özellikle cihat politikasıyla Müslümanların İngilizlere karşı kışkırtılmasıyla başarı sağlanacağına inanmaktadır. Almanya'nın İslam dünyasını İngilizler başta olmak üzere düşmanlarına karşı kışkırtma ve ayaklandırma planları 1914 Ağustosu'nun başlarında başlamıştır (Kılıç, 2015: 153). Almanlar cihat politikasını hayati derecede önemsemişlerdir. Genelkurmay Başkanı von Moltke, 5 Ağustos’ta -İngiltere, Almanya’ya savaş açtıktan bir gün sonra- Alman Dışişleri Bakanlığının cihat için istihbaratçılar ve ajanlar toplamaya başlamasını talimatı vermiştir (Kılıç, 2015: 153). Savaş devam ederken bazı cephelerde ilginç hadiseler olmuştur. Örneğin, İngiliz ordusundaki Hintli askerler Kutülamare Savaşı'nda Osmanlı askerlerini yani dindaşlarıyla çarpışmak istemiyordu. 
Bazı askerler Türkler'e iltica etmişti (Keleşyılmaz, 1999b: 138). Birinci Dünya Savaşı'nda İttifak ya da İtilaf devleri askerlerin hatta esirlerin kendilerini cepheye sürenlere karşı menfi duygular beslemeleri için propagandayı da ihmal etmemişlerdir. (konuyla ilgili ilginç bir çalışma için bkz. Vahdet Keleşyılmaz, "I. Dünya Savaşı'nda Esir Askerler Üzerinde Panislamizm Propagandası Teşebbüsü”, Kebikeç, S. 10, (2000), s. 31-37).

Liman von Sanders başkanlığında bir askerî danışman heyetini Osmanlı Devleti'ne gönderen Almanya sadece diğer Müslümanlara çağrı yapılmasına vesile olacak hilafetin gücünden değil Osmanlının askerinden de sonuna kadar faydalanmayı düşünmüştür. Osmanlı maliyesini rahata kavuşturmak için ciddi bir kredi açan Almanya, Osmanlı'dan Rusya ve İngiltere ile savaşacak yeni cepheler açmasını istemiştir (Yıldız, 2014: 195). Sadece dışarıda problemler yoktur. Osmanlının iç politikalarında da problemler bulunmaktadır. 1914 yılının daha yarısı bile olmadan Doğu Anadolu'da ve İran sınırında tansiyon yükselmeye başlamıştır. İttihat ve Terakki'nin bölgede uyguladığı politikalar yüzünden Kürt-Ermeni dengeleri bozulmuştur. $O$ günlerde Ruslar "Osmanlı Ermenileri savunurken Kürtleri görmezden geliyor" propagandasını yayıyordu. Ruslara inanan Kürt vatandaşlar olmuştur (Ünalp, 2015: 496).

\section{Mahkûmlardan, Eşkıyalardan ve Gönüllülerden Birlik Oluşturma Düşüncesi}

Mahpusların, yani hapsedilenlerin tutulduğu yere hapishane; hakkında hüküm verilmişlere de mahkûm denilir (Devellioğlu, 2004: 567, 565). Mahkûmları hapishanede tutmanın hangi tarihte nerede başladığı net değildir. Genel olarak ilk hapishanelerin Kuzey Avrupa'da görüldügü ve günümüzdeki hapishane formunun buradan dünyaya yayıldığı kabul edilir (Y1ldı, 2015: 92). Osmanlı'da cezalandırma sürgün, kalebentlik ya da zindana atılma şeklindeydi. Tanzimat sonrasında Avrupa'daki hapishane kavramı ve formu Osmanlı Devleti'nde de uygulanmaya başlandı (OratÇelik, 2011: 77). İlk yeni hapishane 1870'de Sultanahmet'te açılmıştır (Y1ld1z, 2015: 78). II. Abdülhamid'in padişahlık döneminde (1876-1909) pek çok alanda olduğu gibi hapishane 1slahatına da önem verildi (Akın, 2011: 25). Hapishane ve tevkifhanelere ait ilk genel hükümler 1880 tarihli "Memâlik-i Mahrûsa-i Şâhânede Bulunan Tevkifhâne ve Hapishânelerin İdâre-i Dâhiliyelerine Dâir Nizâmnâme" başliklı belgedir. Hapishaneler önce Adliye Nezâreti'ne daha sonra ise Dâhiliye Nezâreti'ne bağlanmıştır (Atar, 2011: 88). Her yönden muktedir olmak 
isteyen İttihat ve Terakki Partisi döneminde hapishaneler kurumsal olarak daha ön plana çıktığı söylenebilir (Akın, 2011: 26).

Cumhurbaşkanlığı Devlet Arşivleri Başkanlığı Osmanlı Arşivleri'ndeki belgelerden anlaşılmaktadır ki asker sayısına takviye olabilmesi için gönüllüler haricinde aşiret mensuplarından ve mahkûmlardan da gayrinizami bir birliğin oluşturulması düşünülmüştür. Çalışmada mahkûmlardan asker olarak faydalanma düşüncesi değerlendirileceğinden özellikle aşiretlerden milis gücü oluşturmayla alakalı belgeler/bilgiler kapsam dışı tutulmuştur. Konuyla alakalı çok belge vardır (bkz. BOA, DH.ŞFR, 441/50). Bu husus başlı başına bir çalışmadır. Makalede birkaç yerde aşiret mensuplarıyla alakalı bilgi verilmiştir.

Osmanlı Devleti'nin Almanya ile gizli ittifak antlaşması sonrasında artık dönülmez bir yola girilmiştir. Alman heyetinin görüşleri bu süreçte çok etkili olmuştur. Almanlar kendilerine faydalı olacağını düşündügü Türkleri müttefik ilan etmiştir. Gerçi bu süreç o kadar da kolay olmamıştır. Hem Osmanlı Devleti'nden hem de Almanya'dan bu ittifaka karşı çıkanlar olmuştur. Ama bu itiraz edenlerin sayısı daha doğru bir ifadeyle etkileri fazla olmadığından kısa sürede Türkler ile Almanlar kader birliği yapmıştır. Savaşı kazanmak için en önemli etkenlerden birisi daha çok askere sahip olmaktır. Günümüzde böyle değilse de o yıllarda askerin çok olması savaşın gidişatını değiş̧ire(bile)n önemli bir faktördü ve Osmanlı Devleti de ülkenin doğusundaki aşiretlerden ve mahkûmlardan faydalanmayı gündemine almıştır.

II. Meşrutiyet'in ilanı sonrasındaki süreçte partiler kurulmuş, seçimler yapılmıştı. 1918'e kadar ülkenin kaderini belirleyen İttihat ve Terakki ise bahsi geçen sürecin en etkili teşkilatıydı. Enver, Cemal ve Talat Paşalar da İttihat ve Terakki'nin en etkili aktörleriydi. Tahmin edileceği gibi de kadrolaşma ihmal edilmemişti. İttihat ve Terakki de kendi düşüncelerine muhalif olmayanlarla çalışmayı tercih etmiştir. Savaşın arifesinde ve devamında da bu daha belirgin olmuştur.

Mahkûmlardan, aşiretlerden gayrinizami birlik oluşturma düşüncesi de az önce bahsedilen kadronun kararlarıdır denilebilir. Bitlis Valisi Mustafa Abdülhalik Bey 19 Eylül 1914 tarihinde Dâhiliye Nezâreti'ne çektiği telgrafında orduda dikkat çekici şekilde hizmet edeceklerinden emin olunan mahkûmlar için ceza affının uygun olacağını yazmıştır. Ona göre idam cezası alanların bu süreçte affedilmese bile cezalarının yeniden değerlendirilmesi önemlidir. Vali Abdülhalik de bu öneme dikkat çekmiş̧ir. Vali bu konuda oldukça faydacı ve akılcı düşünmektedir (BOA, DH.ŞFR, 441/50). Ama ne ilginçtir ki aynı vali sadece sekiz gün sonra (27 Eylül 1914) fikir değiştirmiştir. Orduya katılmak için müracaat 
eden mahkûmlara güvenilemeyeceğini, bunların serbest kaldıktan sonra orduya katılmak için sınıra gidip gitmeyeceklerinin oldukça şüpheli olduğunu, zaten serbest bırakılan mahkûmlardan bir kısmının orduya sevk edildikten sonra firar ettikleri ve bu gibilerin serbest birakılmasının uygun olmadığını şifreli telgrafında yazmıştır (BOA, DH.ŞFR, 442/35).

Resmi olarak Osmanlı ile Rusya arasında savaşın başlamasının ardından bölgedeki hareketlilik ziyadesiyle artmıştır. Teşkilat-1 Mahsusa'nın mensuplarından Yusuf Riza Bey'in 12 Ekim 1914 tarihinde Trabzon Vilayeti vasıtasıyla Dâhiliye Nezâreti'ne çektiği telgrafında Teşkilat-1 Mahsusa'ya Akçaabat, Görele ve Vakfıkebir kazalarının eşkıyalarından toplamda bin kişilik bir ekibin dâhil edileceği kayıtlıdır. Üçüncü Ordu Komutanı Hasan İzzet Paşa'ya Enver Paşa tarafından icap eden emrin verilmesi gerektiğini ihtiva eden bu kayıt o günlerdeki ordunun durumu hakkında bilgi vermektedir (BOA, DH.ŞFR, 444/27).

Trabzon Valisi Cemal Azmi Bey'den Dâhiliye Nezâreti'ne çekilen 3 Kasım 1914 tarihli telgrafta Trabzon'daki mahkûmların iç bölgelere sevkinin zor bir iş olduğu, Gümüşhane'deki hapishanelerin mevcut mahkûmları barındıracak durumda olmadığı, Sivas veya başka bir vilayete nakletmenin ise çok masraflı olacağı, yine de sevk emri verilecekse icap eden paranın havale edilmesi ve nereye nakledileceğinin bildirilmesi istenmiştir (BOA, DH.ŞFR, 446/54). Dört gün sonra (7 Kasım 1914) Dâhiliye Nezâreti'nden Trabzon Vilâyeti'ne cevap gelmiş ve cezalarının dörtte üçünü çekmiş olan mahkûmların serbest bırakılması, bunlardan boşalacak yerlere sahil bölgelerinden getirilecek mahkûmların yerleştirilmesi ve bu konuda yapılacak masrafın bildirilmesi talimatı gelmiştir (BOA, DH.ŞFR, 46/210).

9 Kasım 1914 tarihli telgrafta Dâhiliye Nezâreti'nden -sahillerde bulunan- Adana, Trabzon, Beyrut, Kastamonu ve Aydin (İzmir) vilayetleri ile Menteşe, Teke, Kale-i Sultaniye (Çanakkale) ve Kudüs-i Şerif mutasarrıflıklarına mahkûmlardan bir kısmının affedileceği, bir kısmının da iç bölgelere sevk edileceği, bu nedenle hapishane ödeneklerinden bir miktarının harcanmadan kalacağı, tasarruf edilecek miktarın diğer vilayetlere havale edilmek üzere tespit edilerek bildirilmesi talimatı verilmiştir (BOA, DH.ŞFR, 46/267). Bunun üzerine (10-11 Kasım 1914 tarihinde) Trabzon Valisi Cemal Azmi Bey, Dâhiliye Nezâreti'ne çektiği telgrafında vilayette bulunan mahkûmlar içinde aftan yaralanabilecek olanların çok az olduğu, Teşkilat-1 Mahsusa'ya verilecekler de çıkarıldığında en az 3000 mahkûm bulunduğu, vilayetteki diğer hapishanelerin uygun olmaması nedeniyle oralara nakillerinin de imkânsız olduğuna dikkat çekmiştir. Sivas Vilâyeti'ne sevk etmenin ise çok külfetli olacağını, bu nedenle bütün mahkûmların serbest 
bırakılmasının daha münasip olacağını düşünmektedir. Ve yine bir düşman saldırısında bunların (mahkûmların) çok faydası olacağına inanmaktadır (BOA, DH.ŞFR, 447/125). Dâhiliye Nazırı Talat Bey bu görüşler üzerine mahkûmların Trabzon'da kalmasının daha uygun olacağını belirtmiştir (BOA, DH.ŞFR, 46/299).

Yaklaşık bir ay sonra (16 Aralık 1914) Dâhiliye Nazırı namına Emniyet-i Umumiye Müdürü İsmail Canbulat Bey'den Canik Mutasarrıflığına çekilen telgrafta Bafra ve çevresindeki hapishanelerde tutuklu bulunan ve cepheye gitmek isteyen mahkûmlardan çeteciliğe elverişli olanların isimleri ve elbise ile diğer teçhizatın durumunun bildirilmesi istenmiştir (BOA, DH.ŞFR, 48/27).

20 Aralık 1914 tarihinde Sivas Vilayeti'nden Dâhiliye Nezâreti'ne çekilen telgrafta milis faaliyetleri yapmak amacıyla Mihrali aşiretinden Rüştü Bey'in adamlarıyla birlikte Erzurum'a gittiği ve şu an savaş bölgesinde olduğu, Sivas merkezdeki mahkûmlardan şartları milis olmaya uygun görülen 139 kişinin listesinin postayla gönderildiği bildirilmiştir (BOA, DH.ŞFR, 454/93). 22 Aralık 1914'te başlayan Sarıkamış kuşatma harekâtı devam ederken -2 Ocak 1915 tarihindeDâhiliye Nazırı Talat Bey'den Van Vilayeti'ne çekilen telgrafta Van hapishanesinde bulunan mahkûmlardan çetelere katılabilecek olan ve serbest bırakılmaları aşiretler ile ahali üzerinde iyi etki bırakabilecek kişilerden serbest bırakılan 61 kişinin isimlerini gösteren defterin henüz gelmediği ikazı görülmektedir (BOA, DH.ŞFR, 48/240) Bahsi geçen defterin ne zaman postaya verildiğini soran Dâhiliye Nazırı Talat Bey'e Sivas Valisi Ahmed Muammer Bey 6 Ocak 1915'te cevaben Sivas'taki mahkûmlardan çeteciliğe elverişli olanların isimlerini gösteren defterin 21 Aralık 1914 tarihinde posta ile gönderildiğini yazdıktan sonra bazı önemli bilgileri de ilave eder. Buna göre mahkûmlar elbise ve hayvanlarını kendileri tedarik etmiş̧ir. Harekete hazır olan bu kişiler için verilecek emir beklenmektedir. Ayrıca Tokat ve Karahisar-1 Şarki'deki mahkûmlardan çeteciliğe uygun olanların defterinin de telgrafın çekildiği gün (6 Ocak 1915) posta ile gönderildiğini bildirmiştir (BOA, DH.ŞFR, 456/107).

Dâhiliye Nazırı Talat Bey'in 13 Ocak 1915 tarihli telgrafinda "Vilâyât hapishanelerinde mevkûf iken bi't-tahliye çete hâlinde meydan-ı mücâhedeye sevk olunan (...) faide temîn edildiği anlaşılmaktadır" (Komisyon, 2013: 131) ifadesinden kisa süre sonra tersi ifadeler telgraflara yansiyacaktır.

Ocak ayının 25'inde Kastamonu Valisi Mehmet Reşit Paşa da -Sivas Valisi gibi- çetecilikte istihdam edilecek mahkûmlar hakkında verilecek 
izni beklediklerini bildirmiştir (BOA, DH.ŞFR, 459/25). Teke Mutasarrıfı Sabur Sami Bey'den Dâhiliye Nezâreti'ne çekilen 26 Ocak 1915 tarihli telgraf da benzer bir belirsizlikten bahsetmektedir. Telgrafta "çete teşkilatına dair gelen emirde harekete hazır olunması ile teçhizatın Müdafaa-i Milliye tarafindan temin edileceğinin bildirildiği, bunun dişında bunların nerede istihdam edileceğine veya mahkûmların durumuna dair herhangi bir talimat verilmediği" kayıtlıdır (BOA, DH.ŞFR, 459/40). Aynı içerikli telgraflar çoğalmaya başlayınca 30 Ocak 1915 tarihinde Dâhiliye Nezâreti’nden tüm vilayet ve sancaklara çetelere katılmaları için kaydedilen ve sevk emri bekleyen kişiler ile mahkûmlar arasında çeteciliğe uygun olanların miktarının süratle bildirilmesi telgrafi çekilmiştir (BOA, DH.ŞFR, 49/164).

Kastamonu Valisi Mehmet Reşit Paşa'dan Dâhiliye Nezâreti'ne çekilen 31 Ocak 1915 tarihli telgraftaki rakamlar şöyledir: "Kastamonu'da mahkûm:373, -gönüllü- ahali:68; Sinop'ta toplam:118; İnebolu'da ahali: 20; Sinop'tan şu ana kadar beş kafile halinde 118 kişi çeteci olarak cepheye sevk edilmiştir" (BOA, DH.ŞFR, 459/92):

Aynı gün (31 Ocak 1915) Çatalca Mutasarrıfı İbrahim Süreyya Bey’den Dâhiliye Nezâreti'ne çekilen telgrafta çetecilik için ahaliden 50, mahkûmlardan 4 kişinin gönüllü olduğu, bunların hazırlıklarının tamamlanmak üzere bulunduğu ve iki üç gün içinde hareket edebilecekleri, bunlar hakkında emir beklediği bilgisi bulunmaktadır (BOA, DH.ŞFR, 459/96).

Mamuretülaziz Valisi Mehmet Sabit Bey'den Dâhiliye Nezâreti'ne çekilen 1 Şubat 1915 tarihli telgraf düşündürücüdür. Vilayette çeteci ve gönüllü kaydı yapılmadığını, mahkûmlar arasında da güvenilir bir çeteci bulunmadığını yazan Vali, mahkûmlara güvenilemeyeceğinin en büyük delilinin Diyarbakır'dan gönderilen çeteci mahkûmlardan yüzde doksanının daha vilayet sınırından çıkmadan firar etmeleri olduğunu bildirir/hatırlatır (BOA, DH.ŞFR, 460/16).

Elazığg'dan (Mamuretülaziz) bu ikaz yapılırken İzmit ve Balıkesir'den (Karesi) aynı günlerde (3 Şubat 1915) farklı telgraflar gelmiştir. İzmit Mutasarrıfı Ahmed Mazhar Müfid Bey'den Dâhiliye Nezâreti'ne çekilen telgrafta İzmit'te çetecilik için ahaliden 50 ve mahkûmlardan 55 kişinin gönüllü olduğu ve ihtiyaç duyulursa sayının artırılabileceği (BOA, DH.ŞFR, 460/32) aynı gün tarihli ve Karesi Mutasarrıfı Hazan Nazım Bey'den Dâhiliye Nezâreti'ne çekilen telgrafta Karesi Sancağı'nda çetecilik için ahaliden 32 ve mahkûmlardan 341 kişinin kaydedildiği, bunların elbiselerinin zamanında yaptırılabilmesi için işlemlerinin tamamlanarak talimat verilmesinin beklendiği kayıtlıdır (BOA, DH.ŞFR, 
460/41). Yaklaşık iki hafta (17 Şubat 1915) sonra Karesi Mutasarrıfi Hasan Nazım Bey'den Dâhiliye Nezâreti'ne çekilen başka bir telgrafta "Balıkesir'deki mahkûmların elbise ve levazımlarını kendileri temin etmek üzere sadakat ve fedakarlıkla savaşmak üzere cepheye sevkleri için toplu bir dilekçe verdikleri, bu talebe olumlu cevap vermenin uygun olacağını" hatırlatmıştır (BOA, DH.ŞFR, 461/105).

Mahkûmlardan, gönüllülerden oluşan gruplardan bazıları gelecek emrin gecikmesi sebebiyle dağılmıştır. 7 Şubat 1915 tarihli ve Halep Valisi Mehmet Celal Bey'den Dâhiliye Nezâreti'ne çekilen telgrafta Halep Vilâyeti'nde gönüllü alayı teşkiline memur edilen Binbaşı Mehmet Bey'in hazırladığı rapordaki bilgiler nakledilmiştir. Buna göre Halep, Trablusşam, Maraş ve Antep sancakları ile İdlip Kazası'nda mahkûmlardan toplam 968 kişinin çetecilik için gönüllü olduğunu ancak Altıncı Kolordu'nun bunlara ihtiyaç olmadığını bildirmiştir. Bunun dışında Dördüncü Ordu Komutanlığı'nın girişimiyle Araplar, Çerkesler, Rumeli muhacirleri, Kürt ve Türklerden atlı ve piyade 2000 kişi çeteci olarak kaydedilmiştir. Ancak işin ertelenmesi nedeniyle bunlar dağılmışlardır (BOA, DH.ŞFR, 460/75).

Diyarbakır Valisi Halil Hamit Bey'den Dâhiliye Nezâreti'ne çekilen 20 Şubat 1915 tarihli telgrafta asker sayısının artırılması niyetiyle yapılan bu girişimlerin ümit edilen neticeyi sağlayamadığı vurgulanmıştır (BOA, DH.ŞFR, 462/33). Bu telgraftan kisa bir süre sonra (22 Şubat 1915) Musul Valisi Mehmet Reşit Bey'den Dâhiliye Nezâreti'ne çekilen telgraf işlerin ters gittiğini göstermektedir. Dizeyi aşiretine mensup mahkûmlar İran ve Basra cephelerine gönderilmişlerdir. Ancak bunlar sadece çapulculuk yaparak geri dönmüşlerdir (BOA, DH.ŞFR, 462/63).

18 Mart 1915 tarihli ve Bağdat Valisi Süleyman Nazif Bey'den Dâhiliye Nezâreti'ne çekilen telgraf da benzer şeyleri ihtiva etmektedir. Buna göre daha önce gerek olmadıkça mahkûmların tahliyesinden kaçınılması tebliğ edilmiştir. Ancak bu hususa dikkat edilmemiştir ya da edilememiştir. Adliye Nezâreti, tecavüz suçluları dışında kalan mahkûmlardan silahlı hizmete uygun olanlar için işlem yapılması talimatına istinaden Bağdat Vilayetindeki mahkûmlar da tahliye edilmiştir. Ancak, Vali Süleyman Nazif bu mahkûmların çoğunlukla eşirra ve eşkıya olduklarını, bunlardan istenen faydanın sağlanamayacağını bildirmiştir (BOA, DH.ŞFR, 465/86).

Diğer taraftan assker olsun, orduya fayda sağlasın diye düşünülerek salıverilen bu mahkûmlardan şikâyet az değildir. 5 Nisan 1915 tarihli ve Dâhiliye Nazırı Talat Bey'den Sivas Vilâyeti'ne çekilen telgraftan da anlaşılmaktadır ki evdeki hesap çarşıya uymamıştır. Üçüncü Ordu'dan 
bildirildiğine göre, Tokat hapishanesinden salıverilen ve silahlandırılarak Onuncu Kolordu'ya gönderilen gönüllü çetesi köylülere zulüm yapmışlardır. Daha da ileri giderek komutanlarına silah bile çekmişlerdir. Kendilerine emir vermek zorunda olanlara, disiplin için amirlik yapanlara karşı gelmişlerdir. Üçüncü Ordu'nun emrine verilmiş olan mahkûmların cephede zararlı oldukları, bu nedenlerden dolayı artık cepheye gönüllü çete askerinin gönderilmemesi istenmiştir. $\mathrm{Bu}$ telgrafta ayrıca emre itaatsizlik ve köylülere zulmeden mahkûmların kimin emri ile salıverildiği hakkında bilgi verilmesi de istenmiştir (BOA, DH.ŞFR, 51/214). Sivas Valisi Ahmet Muammer Bey'in Dâhiliye Nezâreti'ne çektiği 8 Nisan 1915 tarihli cevabi telgrafında Tokat Mutasarrıflığından alınan bilgi nakledilmiştir. Gönderilen 169 mahkûm 8 jandarma eşliğinde ve silahsız olarak yola çıkmışlardır. Telgraftaki iddiaya göre, Üçüncü Ordu'ya dahil olmadan önce bu mahkûmlar Sivas Vilayeti dahilinde herhangi bir olumsuz davranışta bulunmamışlardır. Sivas valisi bundan sonra verilen emir gereğince cepheye gönüllü sevk edilmeyeceğini bildirmiştir (BOA, DH.ŞFR, 467/35).

Tablo 1: 31 Ocak-8 Nisan 1915 Arasında Çetecilik Faaliyetleri için Hazırlanmış Olan Mahkûm, Sürgün ve Gönüllüler

\begin{tabular}{|l|c|c|c|c|}
\hline & Mahkûm & Gönüllü & Sürgün & Toplam \\
\hline Kastamonu Vilayeti & 373 & 68 & & \\
\hline Sinop & 58 & 47 & 13 & \\
\hline İnebolu & & 20 & & \\
\hline Çatalca & 4 & 50 & & \\
\hline İzmit & 55 & 50 & & \\
\hline Karesi (Balıkesir) & 341 & 32 & & \\
\hline $\begin{array}{l}\text { Halep, Trablusşam, Maraş ve Antep } \\
\text { Sancakları ile İdlip Kazası (toplu } \\
\text { olarak verilmiş̦tir) }\end{array}$ & 968 & & & \\
\hline Tokat & & 169 & & \\
\hline Toplam & $\mathbf{1 7 9 9}$ & $\mathbf{4 3 6}$ & $\mathbf{1 3}$ & $\mathbf{2 . 2 4 8}$ \\
\hline
\end{tabular}

Not: Halep, Trablusşam, Maraş ve Antep Sancakları ile İdlip Kazası ayrı olarak verilmediğinden belgedeki sayılar da toplu olarak gösterilmiştir.

15 Nisan 1915 tarihli ve Bitlis Valisi Mustafa Abdülhalik Bey'den Dâhiliye Nezâreti'ne çekilen telgraftan Ocak ayı başlarında oluşturulan büyük kafilede yeterli sayıda insan bulunmaması nedeniyle bazı mahkûmların Hasankale'ye erzak nakli işinde görevlendirildiği ancak kışın şiddeti ve kafilenin Hınıs ile Hasankale arasında yakalandığg bir tipi nedeniyle başlarında jandarma ve asker olmasına rağmen bunların dağıldıkları öğrenilmektedir. Bu mahkûmlardan bir kısmı da donma tehlikesi geçirdiğinden dolayı tedavi izni verilmiştir. Bir taraftan tipi, bir 
taraftan hastalık gibi hadiseler olurken firsattan istifade firar eden mahkûmların ele geçirilerek yeniden hapishaneye gönderilmeye çalışıldığ 1 da telgrafta olan başka bir bilgidir (BOA, DH.ŞFR, 467/100).

4 Nisan 1915 tarihli telgraf bu sürecin bitişiyle alakalı önemli bir tarihtir. Dâhiliye Nazırı namına Emniyet-i Umumiye Müdürü İsmail Canbulat Bey'den Erzurum, Bitlis, Diyarbakır, Sivas, Trabzon, Mamuretülaziz, Musul ve Van vilayetleriyle Canik Mutasarrıflı̆̆ı'na çekilen telgrafta Harbiye Nezâreti'nin artık cepheye gönüllü çete askeri gönderilmesini istemediği bildirilmiştir. $\mathrm{Bu}$ kararın ardındaki neden yukarıda da bahsedildiği gibi (bkz. BOA, DH.ŞFR, 467/35) "Onuncu Kolordu için gönderilen gönüllü çete askerlerinin köylülere zulüm yaptıkları, komutanlarına silah çekerek karşı geldikleri ve bunların cephede zararlı oldukları" bilgisidir (BOA, DH.ŞFR, 51/209)

9 Mayıs 1915 tarihli ve Mamuretülaziz Valisi Mehmet Sabit Bey'den Dâhiliye Nezâreti'ne çekilen telgrafta Dâhiliye Nezâreti'nin 4 Nisan 1915 tarihli telgrafiyla cephede faydası olmayan ve hatta zararı olan gönüllü mahkûmların bundan böyle gönderilmemesi emredildiğinden, daha önce hazırlanan ve cepheye gönüllü gitmek isteyen mahkûmları gösteren defterin Adliye Nezâreti'ne gönderilip gönderilmeyeceğini suali bulunmaktadır (BOA, DH.ŞFR, 470/72).

Yukarıda anlatılan süreç devam ederken bir de hapishanelerde hijyen, hastalık gibi dertle de uğraşılmıştır. Bazı bölgelerde lekeli humma hastalığının görüldüğü ve hapishanelerin temizliğine dikkat edilmesi gerektiğine dair çekilen telgrafta (DH.ŞFR,50/57) belirtilen kayıtsızlı̆̆ın Aydın (İzmir) Vilâyeti'nde söz konusu olmadığı, zira mevcut hapishanelerinin temizlenerek mahkûmlara Müdafaa-i Milliye Cemiyeti tarafindan çamaşır temin edildiği ve bu konuda bir komisyonun çalışmaya devam ettiği 23 Şubat 1915 tarihli telgraftan öğrenilmektedir (BOA, DH.ŞFR, 462/71). 13 Mart 1915 tarihli ve Halep Valisi Mehmet Celal Bey'den Dâhiliye Nezâreti'ne çekilen telgrafta da hapishanede herhangi bir hastalık görülmediği, ancak vilayete dışardan gelen bazı kişilerde lekeli humma tespit edildiği, bunun üzerine sihhiye memurlarının bir rapor hazırladığı bildirilmiştir. Temizlik ve nezafet icabı hapishanedeki yatak ve yorganlar ile mahkûmların elbiselerinin yenilenmesi gerektiği için 5 bin kuruşa ihtiyaç vardır (BOA, DH.ŞFR, 464/131).

\section{Sonuç}

20. yüzyılın başlarında cereyan eden ve insanlık tarihinde oldukça şiddetli ve geniş etkileri olan Birinci Dünya Savaşı'nın farklı cepheleri 
üzerinde araştırmalar devam etmektedir. Savaşın önemli öznelerinden ve kaybedenlerinden olan Osmanlı Devleti'nin bu savaştaki durumunun halen loş 1şıkta kalan kısımları bulunmaktadır. Osmanlı Devleti Birinci Dünya Savaşı öncesinde içeride ve dışarıda pek çok sorunla karşı karşıya kalmıştır. Siyasi ve iktisadi yönlerden zor günler geçiren Osmanlı Devleti yöneticilerinin girilecek savaştan faydalı çıkacağına inandıkları kayıtlara geçmiştir. Osmanlı Devleti'nin kimin ya da kimlerin yanında savaşa gireceği arayışları ve tartışmaları nihayetinde Almanya ile gizli ittifak antlaşması imzalanmıştır. Her iki devletin yöneticilerinden bu ittifaka itiraz edenler olsa da kısa bir müddet sonra Türkler ve Almanlar kader arkadaşı gibi davranmışlardır. Almanların sözünden çıkmayan bir Türk Ordusu görüntüsü başlı başına bir araştırma konusudur.

Asker sayısının çok olması özellikle de savaşta her devletin en çok önem verdiği hususlardandır. Osmanlı Devleti de Birinci Dünya Savaşı'nın başlarında mahkûmlardan, aşiretlerden gayrinizami birlik oluşturma düşüncesiyle hareket etmiştir. Bazı yöneticiler mahkûmların dikkat çekici şekilde hizmet edeceklerinden emin olmuşlardır. Bu bakışa göre savaş ortamında her türlü menfaat gözetilmelidir ve mahkûmların cephelerde olması hapishanelerde olmasından çok daha faydalıdır. Bazıları da orduya katılmak için müracaat eden mahkûmlara güvenilemeyeceğini, bunların serbest kaldıktan sonra orduya katılmak için sınıra gidip gitmeyeceklerinin oldukça şüpheli olduğunu, zaten serbest bırakılan mahkûmlardan bir kısmının orduya sevk edildikten sonra firar ettikleri ve bu gibilerin serbest bırakılmasının uygun olmadığını vurgulamıştır. Ve ne ilginçtir ki bu iki zıt fikir bazen aynı yöneticiye aittir!

Osmanlı Devleti'nin savaşa girdiği ilk cephe Kafkas Cephesi’dir. 1914 Kasım'ına ait belgelerde Teşkilat-1 Mahsusa'nın emrine en az 3000 mahkûmun verileceği kayıtlıdır. Bir düşman saldırısında mahkûmların çok faydası olacağına inanan yöneticiler bulunmaktadır. 1914 Aralık'ına ait belgelerde Bafra ve çevresindeki hapishanelerde tutuklu bulunan ve cepheye gitmek isteyen mahkûmlardan çeteciliğe elverişli olanların isimleri belirlenmiştir. Mahkûmlar haricinde bazı aşiret mensuplarının cepheye gittiği bilgisi de belgelerde mevcuttur. Cepheye gitmek için gönüllü olan mahkûmlar ile alakalı karar oldukça gecikmiştir. 1915 Ocak'ına kadar bekleyen mahkûmların nerede görevlendirileceği netlik kazanamamıştır. $\mathrm{Bu}$ sürece uzayınca toplanan gönüllülerden ve mahkûmlardan bazıları dağılmıştır. Ülkenin pek çok yerinden mahkûmlar cepheye gitmek için hazır beklemişlerdir. Asker kıyafetlerinin tamamına yakınını da mahkûmlar kendileri üstlenmişlerdir. İncelenen dönemde, 31 Ocak-8 Nisan 1915 arasında çetecilik faaliyetleri için hazırlanmış olan mahkûm, sürgün ve gönüllülerin sayısı toplamda 2.248'dir. 
4 Nisan 1915 tarihli telgraf bu sürecin bitişiyle alakalı önemli bir tarihtir. Dâhiliye Nazırı namına Emniyet-i Umumiye Müdürü İsmail Canbulat Bey'den Erzurum, Bitlis, Diyarbekir, Sivas, Trabzon, Mamuretülaziz, Musul ve Van vilayetleriyle Canik Mutasarrıflı̆̆ı'na çekilen telgrafta Harbiye Nezâreti'nin artık cepheye gönüllü çete askeri gönderilmesini istemediği bildirilmiştir.

Birinci Dünya Savaşı'nın ilk günlerinde Osmanlı Ordusu, Kafkas Cephesinde mahkûmlarla asker sayısını artırmak gibi pragmatik bir düşünceyle hareket etmiştir. Osmanlı Hükümetinin, mahkûmlardan cephede fayda umduğu bu projede başarı -çok az bir istisna haricindemümkün olmamıştır.

\section{Kaynaklar}

Arşiv Belgeleri

BOA, DH.ŞFR, $441 / 50$

BOA, DH.ŞFR, 442 / 35

BOA, DH.ŞFR, 444 / 27

BOA, DH.ŞFR, 446 / 54

BOA, DH.ŞFR, 447 / 125

BOA, DH.ŞFR, 454 / 93

BOA, DH.ŞFR, 456 / 107

BOA, DH.ŞFR, 459 / 25

BOA, DH.ŞFR, 459 / 40

BOA, DH.ŞFR, 459 / 92

BOA, DH.ŞFR, 459 / 96

BOA, DH.ŞFR, 46 / 210

BOA, DH.ŞFR, 46 / 267

BOA, DH.ŞFR, 46 / 299

BOA, DH.ŞFR, 460 / 16

BOA, DH.ŞFR, 460 / 32

BOA, DH.ŞFR, 460 / 41

BOA, DH.ŞFR, 460 / 75 
BOA, DH.ŞFR, 461 / 105

BOA, DH.ŞFR, 462 / 33

BOA, DH.ŞFR, 462 / 63

BOA, DH.ŞFR, 462 / 71

BOA, DH.ŞFR, 464 / 131

BOA, DH.ŞFR, 465 / 86

BOA, DH.ŞFR, 467 / 100

BOA, DH.ŞFR, 467 / 35

BOA, DH.ŞFR, 470 / 72

BOA, DH.ŞFR, 48 / 240

BOA, DH.ŞFR, 48 / 27

BOA, DH.ŞFR, 49 / 164

BOA, DH.ŞFR, 51 / 209

BOA, DH.ŞFR, 51 / 214

\section{Telif Eserler}

Akın, H. (2011), “Osmanlı Devleti'nde Hapishane Islahatına Dair 1893 Tarihli Bir Nizamname Önerisi”, History Studies, C.3/3, s.23-36.

Akşin, S. (1997), Türkiye ’nin Yakın Tarihi, C.1, İmge Yayınları

Aruçi, M. (2009), "Saraybosna”, TDİA, C. 36. s.128-132.

Atar, Z. (2011), “20. Yüzyılın Başlarında Turgutlu Hapishanesi’nin Genel Durumu", Celal Bayar Üniversitesi Sosyal Bilimler Dergisi, C.9, S.1, s.87-102.

Bardakçı, M. (2013), İttihadçının Sandığı, İş Bankası Yayınları, İstanbul

Demirtaş, M. (2018), “1914 Tarihli Bitlis İsyanının Osmanlı Arşiv Belgelerindeki Yansımalar1-Cezalar, Mükâfatlar”, Bitlis Eren Üniversitesi Sosyal Bilimler Enstitüsü Dergisi, C.7, S.2. s.432-492.

Devellioğlu, F. (2004), Osmanlıca-Türkçe Ansiklopedik Lûgat, (21.Bask1), Aydın Kitabevi, Ankara

Hacısalihoğlu, M. (2009), “Sirbistan, Tarih”, TDİA, C. 37. s.121-126.

Karal, E. Z. (tarihsiz), Osmanlı Tarihi, C.V, TTK Yayınları

Karaca, E. (2011), “Türk Basınında Alman Askeri Islahat Heyeti 
Meselesi (1913-1914)", Gazi Akademik Bakış, C.5, S.9, s.203-212.

Komisyon. (2013), Osmanlı Belgelerinde Birinci Dünya Harbi, T.C. Başbakanlık Devlet Arşivleri Genel Müdürlüğü Yayınları, İstanbul

Yazıc1, S. (2018), Osmanlı Meclis-i Mebusanı ve Faaliyetleri (19141918), Yayımlanmamış Doktora Tezi, Afyon Kocatepe Üniversitesi Sosyal Bilimler Enstitüsü, Afyon

Karaca, T.N. (2015), “Birinci Dünya Savaşı'na Giden Yolda Kara El Grubu ve Franz Ferdinand'a Suikast", 100. Yılında I. Dünya Savaşı Uluslararası Sempozyumu, Atatürk Kültür, Dil ve Tarih Yüksek Kurumu Atatürk Araştırma Merkezi Yayınları, Ankara, s.91-108.

Keleşyılmaz, V. (1999a), “Belgelerle Türkiye’nin Birinci Dünya Savaşı'na Giriş Süreci”, Erdem, C.11, S.31, s.139-153.

Keleşyılmaz, V. (1999b), Teşkilât-ı Mahsûsa'nın Hindistan Misyonu (1914-1918), Atatürk Araştırma Merkezi Yayınları

Keleşyılmaz, V. (2000), “I. Dünya Savaşı'nda Esir Askerler Üzerinde Panislamizm Propagandası Teşebbüsü”, Kebikeç, S.10, s. 31-37.

K1lıç, S. (2014), “Birinci Dünya Savaşı’na Uzanan Süreçte Türk-Alman Yakınlaşması", 1914'ten 2014'e 100'üncü Yılında Birinci Dünya Savaşı'nı Anlamak Uluslararası Sempozyumu, 20-21 Kasım 2014 İstanbul, Harp Akademileri Komutanlığı Stratejik Araştırmalar Enstitüsü Yayınları, s.91-154.

Kılıç, S. (2015), “I. Dünya Savaşı'nda Türk-Alman Cihat Politikasına Bir Bakış", 100. Y1lı münasebetiyle I. Dünya Savaşı’nda Kafkas (Doğu) Cephesi Uluslararasi Sempozyumu 25-27 Eylül 2014/Erzurum, Atatürk Araştırma Merkezi Yayınları, s.139-187.

Kuran, E. (1992), “Birinci Dünya Savaşı”, TDİA, C.6, 1992, s.196-200.

Okur, M. S. Göktaş (2014), "Birinci Dünya Savaşı Sürecinde Meclis-i Umumi'de Görüşülen Başlica Askerî Meseleler”, 1914'ten 2014'e 100'üncü Yılında Birinci Dünya Savaşı'nı Anlamak Uluslararası Sempozyumu, 20-21 Kasim 2014 İstanbul, Harp Akademileri Komutanlığg Stratejik Araştırmalar Enstitüsü Yayınları, s.283-311.

Orat, J. Çelik, F. (2011), "Diyarbakır Vilayeti Hapishaneleri”, Sosyal Bilimler Enstitüsü Dergisi, S.7, s.73-95.

Ortak, Ş (2015), “Sarıkamış Harekâtı Öncesi Kafkas Cephesi’ne Deniz Nakliyatı ve Yaşanan Deniz Savaşları", 100. Yılı münasebetiyle I. Dünya Savaşı'nda Kafkas (Doğu) Cephesi Uluslararası 
Sempozyumu 25-27 Eylül 2014/Erzurum, Atatürk Araştırma Merkezi Yayınlar1, s.283-308.

Turan, M (2015), "I. Dünya Savaşı Öncesinde Avrupa Devletlerinin Siyaset Stratejileri ve Osmanlı Devleti", 100. Yılında I. Dünya Savaşı Uluslararası Sempozyumu, Atatürk Kültür, Dil ve Tarih Yüksek Kurumu Atatürk Araştırma Merkezi Yayınları, Ankara, s.57-89.

Ünalp, R (2015), “Birinci Dünya Harbi Sirasında Kafkas Cephesi'ndeki Casusluk Faaliyetleri (1914'ten 1918'e kadar)", 100. Yll münasebetiyle I. Dünya Savaşı'nda Kafkas (Doğu) Cephesi Uluslararası Sempozyumu 25-27 Eylül 2014/Erzurum, Atatürk Araştırma Merkezi Yayınları, s.493-530.

Yıldız, G (2014), "Birleşik Harekât Tecrübesi Olarak Cihan Harbinde Türk-Alman Askerî İttifakı”, 1914'ten 2014'e 100'üncü Yılında Birinci Dünya Savaşı'nı Anlamak Uluslararası Sempozyum 20-21 Kasım 2014 İstanbul, Harp Akademileri Komutanlığı Stratejik Araştırmalar Enstitüsü Yayınları, s.191-202.

Yıldız, Ö. (2015), “Osmanlı Hapishaneleri Üzerine Bir Değerlendirme: Karesi Hapishanesi Örneği”, Akademik Bakış, C.9, S.17, s.91-111. 


\section{Ekler}

Ek 1: Hizmet Edeceği Düşünülen Mahkûmlar için Ceza Affının Uygun Olacağı Hakkında Bitlis Valisi Mustafa Abdülhalik Bey'den Dâhiliye Nezâreti'ne Çekilen 19 Eylül 1914 Tarihli Telgraf

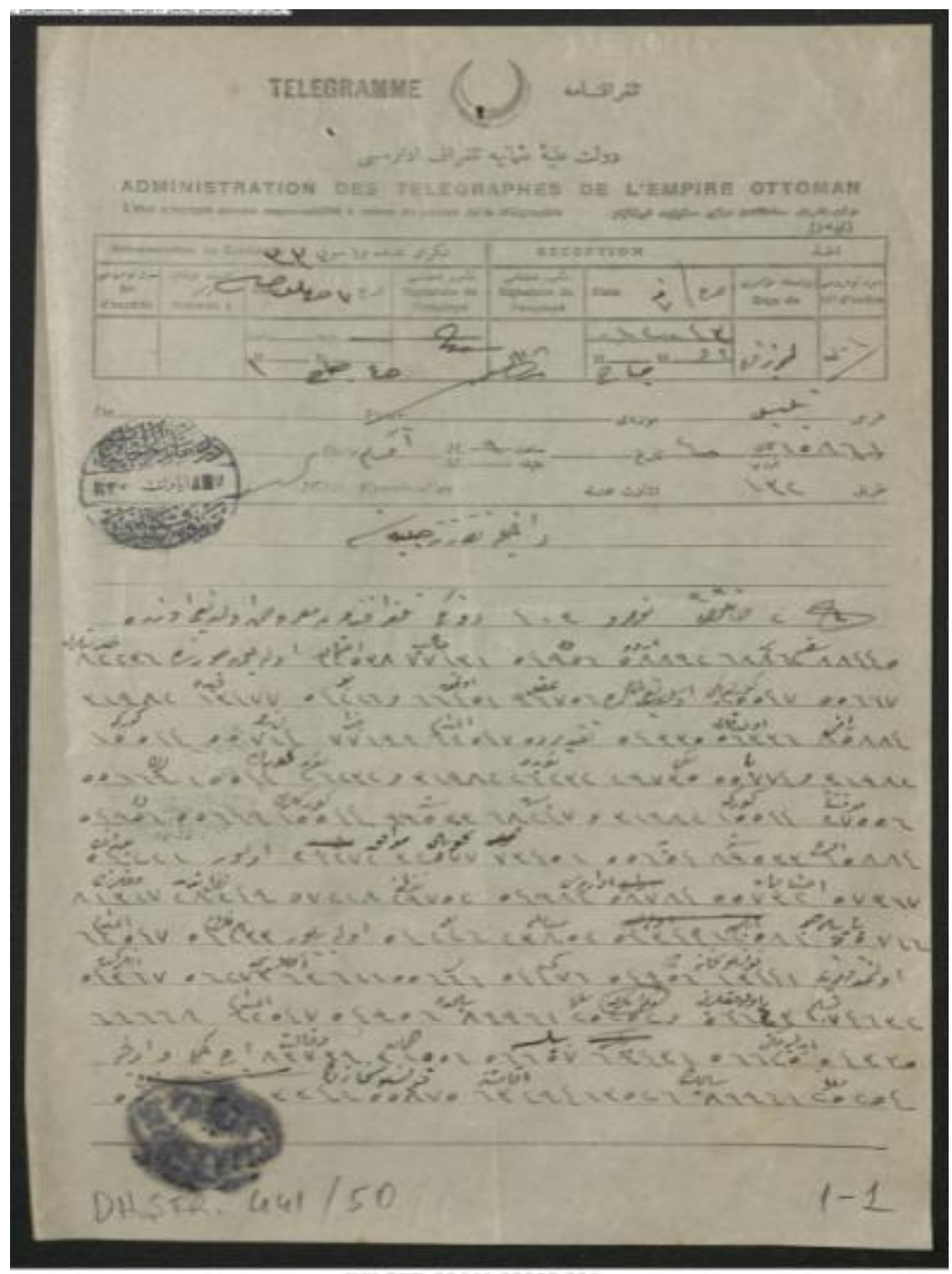

DH.SFR.00441.00050.001

Kaynak: BOA, DH.ŞFR, 441/50. 
Ek 2: Mahkûmlardan İstenen Faydanın Sağlanamayacağı Hakkında Bağdat Valisi Süleyman Nazif Bey'den Dâhiliye Nezâreti’ne Çekilen 18 Mart 1915 Tarihli Telgraf

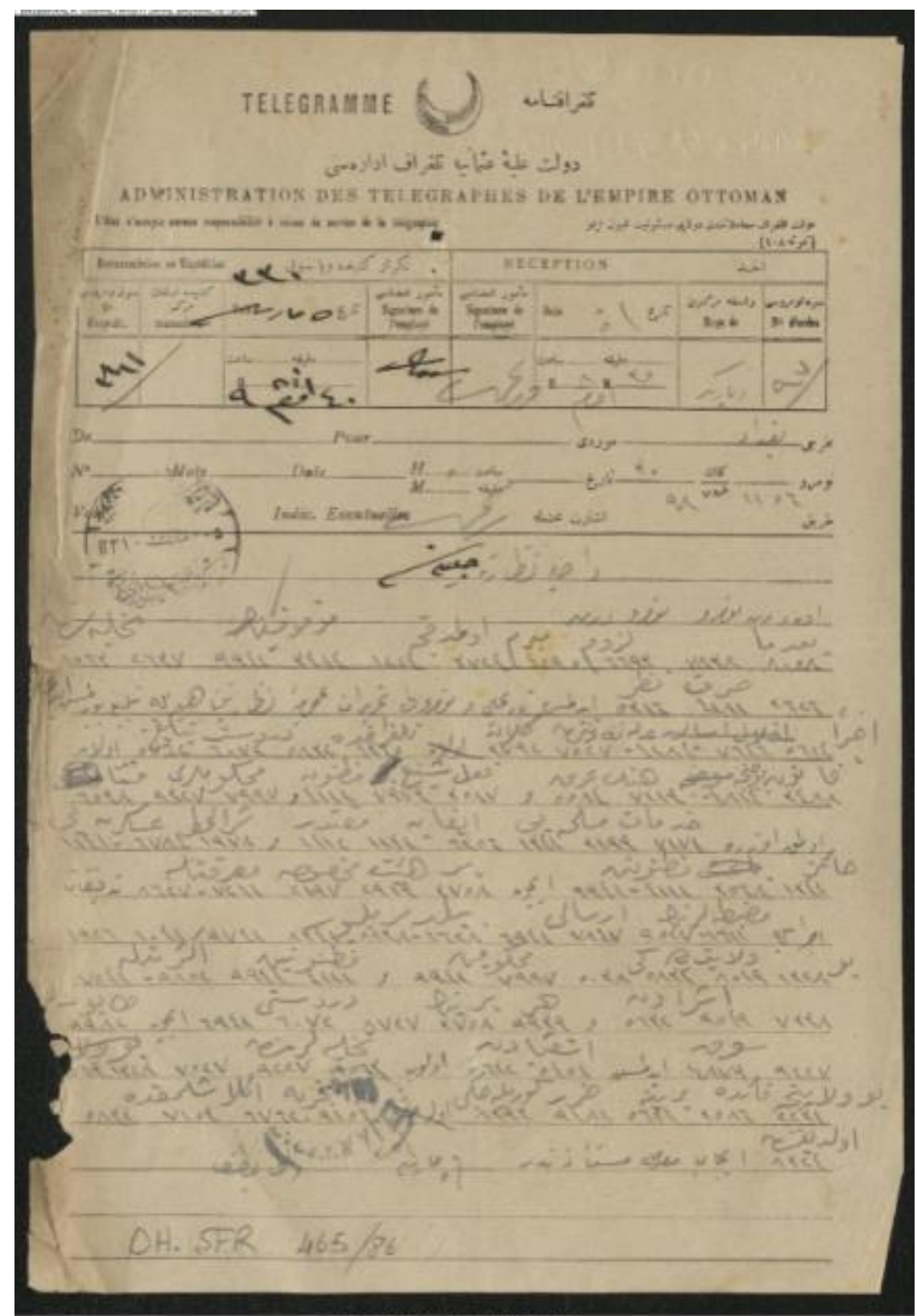

DH.SFR. 00465,00086,001

Kaynak: BOA, DH.ŞFR, 465/86. 
